\title{
Ursinia nana (Anthemideae, Asteraceae), an adventive from South Africa which is becoming naturalized in the NE Iberian Peninsula. Observations about its reproductive biology and fruit dispersal mechanisms
}

\author{
J. MOLERO BRIONES
}

Laboratori de Botànica, Facultat de Farmàcia, Universitat de Barcelona, 08028 Barcelona, Spain.

Email: jmolero@ub.edu

Received 27 April 2009; Accepted 3 September 2009

\begin{abstract}
The presence of Ursinia nana, an Anthemideae of South-African origin which has been introduced into the NE Iberian Peninsula, is reported for the first time in Europe. The data offered cover its precise location, morphology, chromosome number, ecology and a population census, as well as its life cycle, floral structure, reproductive biology and fruit dispersal mechanisms. Of special note are the clear predominance of autogamy (geitonogamy) over xenogamy as a reproductive system and the large number of fruits produced with high and immediate germinative capacity. These characteristics permit rapid colonization by the introduced species, which can become invasive. However, fruit predation by the ant Messor barbarus points to a natural mechanism that helps regulate population growth and makes biological control possible. Finally its possibilities of expansion in the colonized area and of naturalization in the NE Iberian Peninsula are assessed.
\end{abstract}

Key words: annuals; autogamy; Catalonia; floral structure; fruit predation; geitonogamy; Messor barbarus; naturalization process; pollination ecology; Spain; Ursinia.

\section{Resumen}

Ursinia nana (Anthemideae, Asteraceae), una adventicia de Sudáfrica en proceso de naturalización en el noreste de la península Ibérica. Observaciones sobre su biología reproductiva y sus mecanismos de dispersión de los frutos.- Se indica por primera vez para el continente europeo la presencia de Ursinia nana, una Anthemideae de origen sudafricano introducida en el NE de la Península Ibérica. Además de su localización precisa, morfología, número cromosómico, ecología y de un censo de sus poblaciones, se ofrecen datos sobre el ciclo vital, estructura floral, biología reproductiva y dispersión de los frutos. Son remarcables el claro dominio de la autogamia (geitonogamia) sobre la xenogamia como sistema reproductivo y la alta producción de frutos con elevada e inmediata capacidad germinativa, características que permiten una colonización rápida de esta especie introducida que pudiera devenir invasora. No obstante la predación de sus frutos por la hormiga Messor barbarus evidencian un mecanismo natural que interviene en la regulación del crecimiento de sus poblaciones, lo que puede permitir su control biológico. Finalmente se analizan las posibilidades de expansión en el área colonizada y de su posible naturalización en el NE de la Península Ibérica.

Palabras clave: autogamia; Cataluña; depredación de los frutos; España; especies anuales; estructura floral; geitonogamia; polinización; Messor barbarus; proceso de naturalización; Ursinia. 


\begin{abstract}
Resum
Ursinia nana (Anthemideae, Asteraceae), una adventícia d'Àfrica del sud en procés de naturalització al nord-est de la península Ibèrica. Observacions sobre la seva biologia reproductiva i els seus mecanismes de dispersió dels fruits.- La presència d'Ursinia nana, una Anthemideae d'origen sud-africà introduïda al NE de la Península Ibèrica, s'assenyala per primera vegada al continent europeu. A més de la seva precisa localització, morfologia, nombre cromosòmic, ecologia i un cens de les seves poblacions, s'ofereixen dades sobre el cicle vital, estructura floral, biologia reproductiva i dispersió dels fruits. Cal remarcar el clar domini de la geitonogàmia sobre la xenogàmia com a sistema reproductiu i l'abundant producció de fruits amb elevada i immediata capacitat germinativa, característiques que permeten a aquesta espècie introduïda una ràpida colonització que podria esdevenir invasora. Malgrat tot, la predació dels seus fruits per la formiga Messor barbarus posa de manifest un mecanisme natural que intervé en la regulació del creixement de les seves poblacions, la qual cosa permet un cert control biològic. Finalment s'analitzen les possibilitats d'expansió en el ària colonitzada i la seva possible naturalització en el NE de la Península Ibèrica.
\end{abstract}

Paraules clau: autogàmia; Catalunya; Espanya; espècies anuals; estructura floral; geitonogàmia; Messor barbarus; pol·linització; predació dels fruits; procés de naturalització; Ursinia.

\section{INTRODUCTION}

In the course of a floristic prospection campaign in the Priorat comarca (Catalonia, Tarragona Province, Spain) in May 2006, we detected a large population of small, early-flowering annual Anthemideae with attractive yellow flowers in the vicinity of Falset, towards Gratallops. After a laborious study, the species was identified as Ursinia nana subsp. nana (Anthemideae, Asteraceae) (Fig. 1), a plant of South African origin that has never previously been cited as an adventive in the Iberian Peninsula or Europe.

Of all the species in the genus, U. nana has the largest distribution area. Subsp. nana is found throughout SW Africa (Prassler, 1967), Cape Province (Bond \& Goldblatt, 1984), South Africa (Retief \& Herman, 1997), Pretoria (Wyk \& Malan, 1988), Rhodesia, Botswana, Lesotho and Natal (Hilliard, 1977), Ethiopia, Eritrea and W Australia (Prassler, 1967) (Fig. 2). There is discussion about its spontaneous presence in the countries along the Nile, but it is an introduced species in Australia and New Zealand, where it behaves as a weed and tends to spread rapidly (Scott \& Panetta, 1993).

In South Africa, species of Ursinia tend usually to be semi-nitrophilous, living on acid, sandy, disturbed ground. Herman (pers. comm.) indicates that $U$. nana susp. nana should be considered a pioneer species in disturbed places and a weed in certain semi-nitrophilous places. Hilliard (1977) comments that in Natal it lives in somewhat ruderalized pastures between 600 and $1600 \mathrm{~m}$.
Though it is an exotic plant with respect to the local flora, it has adapted perfectly to the colonized enclave because it originated in a similar Mediterranean-type climate, and in Falset it finds a flowering time and habitat which bears a certain likeness to the genuine habitat of the South African fynbos. Thus it affords an excellent opportunity for a medium- and long-term comparison of the life strategies of native species and alien species from South Africa which have adapted to a similar Mediterranean-type climate. However we felt it was desirable to give a preliminary publication to certain essential aspects. Some initial goals to set are:

1. To precise some morphological-descriptive and taxonomic aspects. For example, the only reasonably complete description of the plant since De Candolle's protologue is by Prassler and was written in Latin and German (1967). Some short or very short diagnostic reports in English are to be found in various South African floras (Hilliard, 1977; Bond \& Goldblatt, 1984; Retief \& Herman, 1997, and others). Consequently we considered it opportune to provide a more detailed description of the Spanish population, along with the first complete iconography of the plant.

2. To shortly describe the special distribution of the invasive colony by placing the subpopulations, quantifying them when possible and describing the habitat where they live.

3. To investigate the possible origin of the introduction by observations on the field, ethnofloristic survey to the area's inhabitants and bibliographic research. 


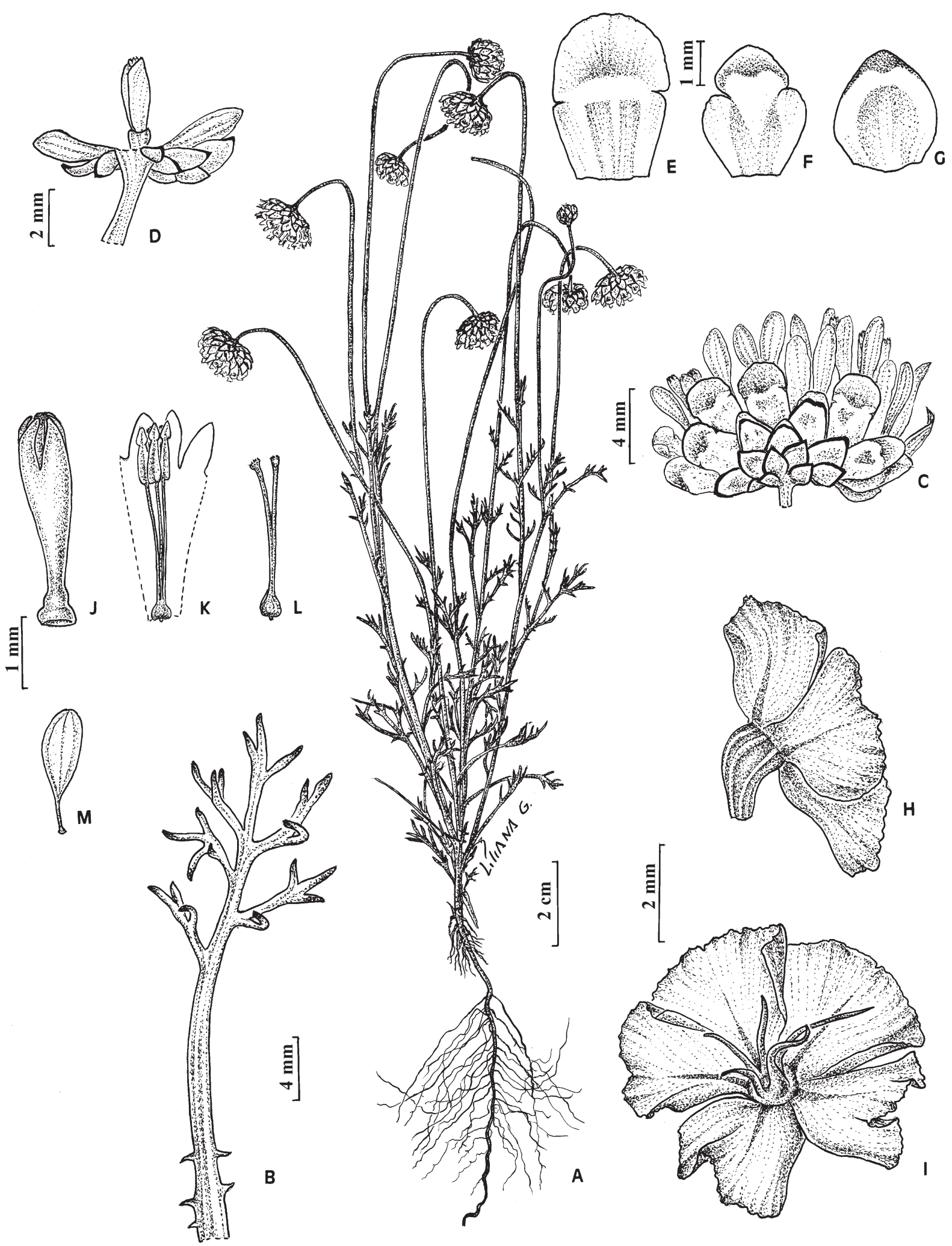

Figure 1. Ursinia nana subsp. nana (Falset, J. Molero 32/2006 \& J. Vallverdú, BCN 46738). (A), habit; (B), leaf from the middle part of the stem; $(\mathrm{C})$, radiate capitulum with marginal ligulate flowers and multiseriate involucre; (D), insertion in the thalamus of a central tubulous flower covered by its \pm utricular palea (receptacular scale); (E), (F), (G), descending series of bracts on the multiseriate involucre; $(\mathrm{H})$, cypsela with its perianth scales, side view; (I), polar view of the cypsela, showing the narrow internal linear scales; $(\mathrm{J})$, closed tubulous flower; $(\mathrm{K})$, stamens; (L), pistil; $(\mathrm{M})$, sterile marginal ligulate flower. 
4. To bring new observations about vegetative and floral structures and reproductive biology of the Spanish colony in order to compare it with South-African populations of the same species or with other African annual species of Ursinia with a similar habitat, if there is previous literature.

5. To look for possible predation processes of insects and other animals on leaves, flowers or seeds of the Spanish colony that may lead us to a possible biological control of the invasion.

6. To reason out the possible future scenario for this invasive colony, if it goes towards its complete naturalization in that area or towards extinction.

These observations serve as an introduction to a more exhaustive later study.

\section{MATERIAL AND METHODS}

The identification and descriptive morphology were based on numerous herbarium samples gathered in the three most significant nuclei of population in the reference locality: Spain, Catalonia, Falset, at a distance of $1.6 \mathrm{~km}$ in the direction of Gratallops, Els Costers de les Aubagues (UTM 31TCF 1655), 330-350 m, $J$. Molero 32/2006 \& J. Vallverdú (BCN 46738).

The chromosome number during mitosis was obtained from root meristems of plants from the aforementioned locality that were cultivated in the Jardí Botànic de Barcelona (JBB) and processed by the usual techniques (Molero \& Rovira, 2002).

The census of pollinators was conducted by means of 30-minute watching periods, separated by 15 -minute rests, between 11.00 and 14.00 hours (intervals of maximum insect activity in the locality) on 12 days in April and May 2007 and one day in July 2008. Thus the observations lasted a total of 39 hours.

Observations of the life cycle, flower structure, reproduction, fruit dispersal and germinative capacity of the seeds were conducted on wild populations and on 50 specimens grown from seeds gathered in the wild from the reference population and cultivated in the JBB.

The insect exclusion test was performed in a greenhouse in the JBB by isolating 30 specimens (one per pot) with a fine nylon net. Isolation of individual capitula in a plastic bag proved unsatisfactory because it led to necrosis of the peduncle, premature falling, and deficient ripening of the capitulum when viable. The pots were placed together in the greenhouse and protected from draughts with circular plastic sheets so as to preclude the possibility of anemophily. Seed production was analysed in 60 capitula taken from all the selected plants, though quite a few cypselae did not reach total maturity. Their viability was not investigated afterwards.

Germination tests on fruits of $U$. nana were carried out by two methods. In the laboratory seeds were sown in Petri dishes on filter paper moistened with distilled water and a fungicide (Thisulam1535-Novara) at room temperature $\left(26^{\circ} \mathrm{C}\right)$ in the presence of light (advisable for small seeds: Schütz et al., 2002). In the greenhouse at the $\operatorname{JBB}\left(25^{\circ} \mathrm{C}, 60 \%\right.$ humidity, indirect daylight $)$ they were sown in germinators in a sandy substratum containing peat. In both cases the cypselae had been gathered in May 2007, stored in a refrigerator at $10^{\circ} \mathrm{C}$ without light, and sown three months later, in September of the same year.

\section{RESULTS AND DISCUSSION}

\section{Taxonomic and descriptive aspects}

Ursinia nana DC., Prodr. 5: 690 (1836) subsp. nana [=U. abyssinica Sch. Bip. ex Walp., Rep. 4: 182 (1847); =U. annua Less. ex Harv. in Fl. Cap. 3: 152 (1865); = Sphenogine pallida DC., Prodr. 5: 682 (1836)].

Icon.: Fig. 1; Figs. 3, 4, 5 (Photo).

Annual 5-28 cm, glabrous, pubescent or pubescent and glandulous; subsimple to very ramified in the lower 1/3-1/2, with erect-ascending branches; striate stems, \pm pubescent, with hairs applicate to erect-patent, 0.2-0.5 mm long; sometimes with sessile glands. Usually with leaves from the base. Leaves $1-3.5 \mathrm{~cm}$ long, erect-patent or patent, somewhat fleshy, oblong or elliptical in shape, with a petiole no more than $1 / 4$ of the lamina, widening at the base and laterally laciniate; lamina 1-2(3) pinnatisect, with leaflets 2-6 x 0.5-1(2) mm, canaliculate or flat, acute, apiculate or mucronate (mucro up to $2 \mathrm{~mm}$ ), glabrous to pubescent, with sessile glands. Single capitulum at the apex of the stem on a long peduncle measuring up to $12 \mathrm{~cm}$, glabrous, radiate; involucre $10-15 \mathrm{~mm}$, bracts at 3-5 levels (multiseriate), the lower and middle 


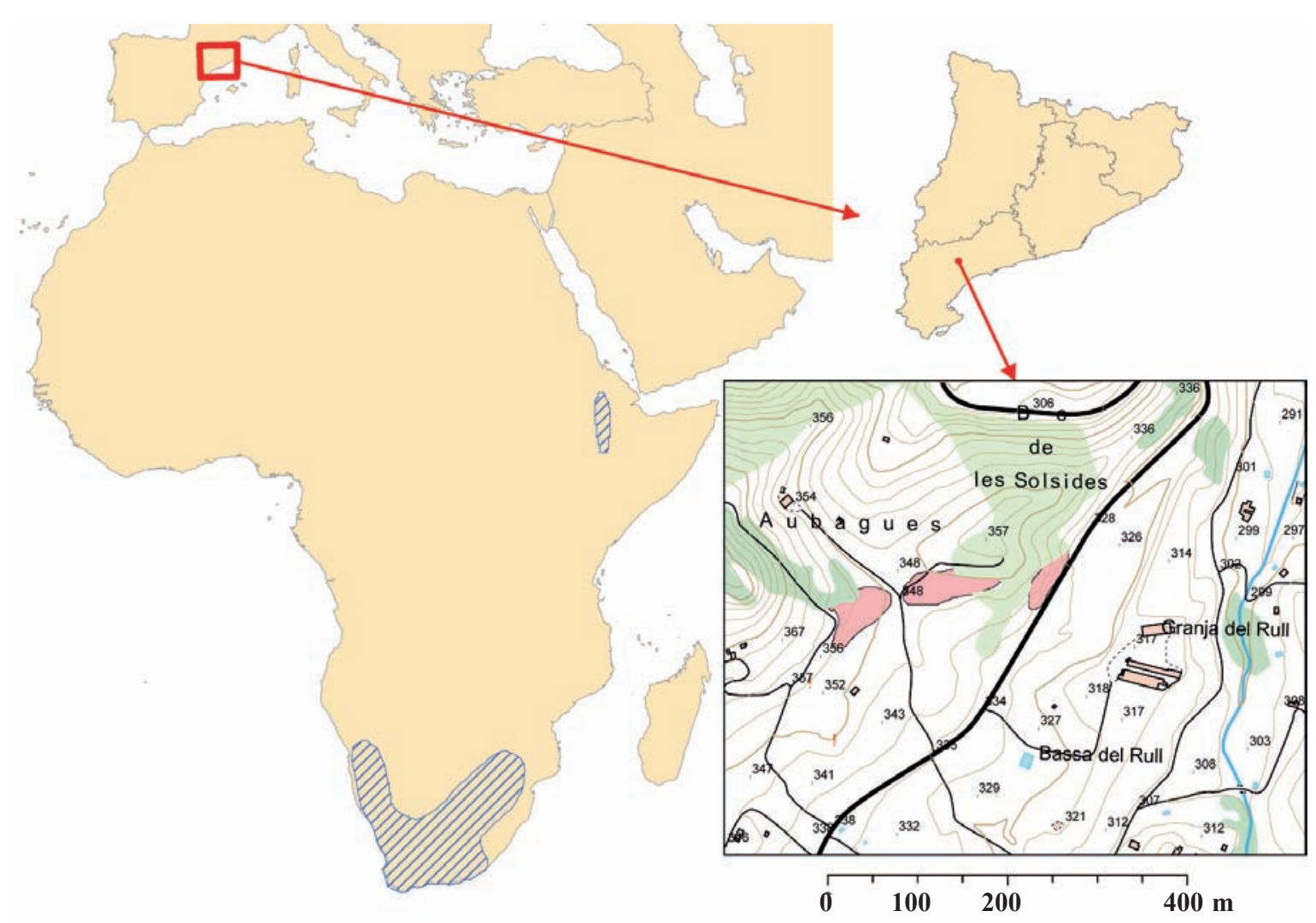

Figure 2. World distribution map of Ursinia nana subsp. nana (except Australia and New Zealand) and location of the three sub-populations in Falset (Priorat, Catalonia, Spain).

ones narrowly edged with black, ovate-elliptical; the innermost ones 3-4 x 2.3-2.7 mm, sub-oblong, with scarious appendices maculate at the base, not marginate, semicircular to broadly ovate, $1 / 3-1 / 2$ of the overall length of the bract. Outer ligulate flowers sterile, 3-6 mm long; limb 3-4 $\mathrm{mm}$ long and tube 1.8-3 mm long, oblanceolate, sub-acute to obtuse, multicoloured, face yellow, reverse pink or reddish with 5-6 clearly marked red nerves on the back. Disc with 8-24 tubulous flowers, 2-3 mm, with lobes $1 / 4$ $-1 / 5$ of the length of the tube, hermaphrodite, yellow; stamens with welded anthers included in the floral tube, $1 / 3$ of the overall length of the stamen; style slightly shorter to slightly longer than the anthers, upper half divided into two stylar arms which open entirely; stigmas obconic, truncate-papillose. Paleae navicular to sub-erect, membranous, slightly shorter than the tubulous flowers they surround, apically truncate. Cypsela 2-2.5 x 1-1.2 mm, obliquely obovate, with 8-10 marked ribs. Biseriate pappus with 5 broad white sepaloid scales, \pm obovate, $3-4$ × 2-3 mm, with a brown stain on the base, ovate-triangular, surroun- ding 5 internal narrow setaceous white scales, of the same length or shorter than the external ones, slightly unequal, soldered onto a basal crown.

\section{Chromosome number}

$2 n=16$ (Fig. 3; Haessler, 1967). We confirm the somatic number shared by nearly all the species in the genus, which has the base number $x=8$; disploidy is very occasionally found in certain species, with $2 n=14$ chromosomes.

\section{Taxonomic position}

Ursinia includes about 37 species of South African distribution, divided into two subgenera: Sphenogyne and Ursinia. U. nana belongs to the latter and is part of the series Nanae, which comprises 6 very similar species that differ from one another by few characters related notably to the shape and consistency of their involucral bracts (Prassler, 1967). It can be distinguished from the most closely related species, $U$. montana DC., which has curved branches and 
attenuated lobes, by its erect branches and abruptly mucronate leaf lobes. In terms of intra-specific variation, Prassler (1967) distinguishes subsp. nana from subsp. leptophylla Prassler (confined to South Africa) by the fact that the former is an annual, not a perennial, and by its somewhat fleshy leaves that are divided several times with lobes of $0.2-0.6 \mathrm{~cm}$, in contrast to the larger, pinnatipartite leaves with lobes of 1-2 cm found in subspecies leptophylla.

\section{Ecology and structure of the colony}

In Falset the species colonizes parts of the southern slope of a sandstone (sauló) outcrop produced by the weathering of granite rock intercalated with neutral Palaeozoic schist (licorella), which is very widespread in this comarca, in a fairly small enclave measuring approximately $0.6 \mathrm{~km}^{2}$ known as "Els Costers and Les Solsides de les Aubagues". So far 3 large nuclei of population have been detected (Fig. 2). In 2007, they varied in size from $c$. 630 individuals in the smallest colony, which is at the lowest altitude (location 3 on the map) beside the road, to $c .2260$ individuals in the intermediate colony (2) and c. 4600 in the highest colony (1), which is probably the oldest and founding colony. This is a total of about 7500 individuals. Annual fluctuations, due basically to rainfall and temperature, can of course be very wide. They form dense communities on initial bare ground, or looser communities in mixed therophytic pastures, and stretch along an imaginary line some $400 \mathrm{~m}$ long, running in a SW-NE direction along the edge of the holm oak and pine wood of Quercus ilex subs. ilex and Pinus pinea, in which thin scrub alternates with pastures of annuals. Ursinia nana forms part of various communities, some of which, such as the silicicolous pastures of Helianthemion guttati, on very sandy, distinctly acid ground, are not at all altered. Elsewhere it is found in ill-defined transitional communities lying between habitats near the edge of the wood, arable land and the edge of a forest track, which are somewhat altered by anthropic activity. It is widespread in clearings in the holm-oak wood, in scrub of Cistus monspeliensis, C. albidus, Lavandula stoechas, Anthyllis cytisoides and Thymus vulgaris, where it is found amid a mixture of strictly silicicolous annuals, some of them characteristic of crop fields, and others that are semi-nitrophilous in tendency.

\section{Populations origin}

We find no reasonable explanation of how this alien species was introduced into this spot. The countryside is a blend of farm- and woodland, typical of the comarca of Priorat. Human presence is evenly divided between farming, woodland management by ancestral methods, and a few isolated dwellings. Dry-land crops alternate with cereal crops, vineyards, almond groves and a few orchards, bordering on the little-exploited woodland. The Ursinia populations colonize small sunny slopes beside the woods, but do not extend into the thick grassland or the disturbed soil of arable land or fallow land and do not act here as a weed. An ethnofloristic survey we conducted among the few farmers and other inhabitants of the area (there are 3 small rural dwellings and a pig farm quite close to the enclave) produced no indication that the species was grown for ornamental purposes. It is not used as a melliferous species by the few beekeepers with hives in the vicinity either. Nor is it found in the few nearby vineyards, where the vines are of a native variety (garnacha) and no South African stocks or other allochthonous elements have been introduced. To our knowledge no ornamental variety of Ursinia is grown there: at least we saw none and our surveys detected none in the nearby locations of Falset or Gratallops.

Everett (1982) mentions U. cakilifolia and $U$. chrysanthemoides are grown in nurseries in Europa. Cullen (2000) adds $U$. anethoides, $U$. anthemoides and $U$. speciosa to the list. There is no mention of $U$. nana being used for this purpose, though seeds of this species can now be purchased on the Internet for ornamental use. It is also cited as a weed in the worldwide data base (GCW, 2007).

On the basis of available data its appearance in this enclave must be considered an unsolved mystery. The large number of individuals, the relative extension and present stability of the populations indicate -notwithstanding its efficient propagation methods- that its introduction cannot have occurred very recently, if one assumes that it originated from a single seed or capitulum. We infer that the colonization process cannot have lasted less than 5-8 years, which considerably predates the effective marketing of the seeds on the Internet (from 2006 onwards). 


\section{Observations about its life-history, phenology, floral architecture and reproductive biology in Spain}

\section{Life-history and phenology}

The species has an annual cycle and in southern Africa bears flowers and fruit in (May) July to December (January), depending on latitude, altitude and seasonal rainfall (Prassler, 1967; Hilliard, 1977). In Falset the cycle begins very early in spring (late February-March) if it has rained during the winter; the flowers open in late March or April, and fruits are borne in May; senescence and shrivelling up occur in June. However, if post-summer or autumn rains fall (September-October), there can be a second phase of less abundant germination and flowering, and fructification continues into November. After the exceptionally warm winter of 2007 , the first rain in February produced a demographic explosion of seedlings and by the end of the month a few individuals were already in flower. The seeds appear to retain a high germinative potential, practically without dormancy. This is conducive to the sudden, massive appearance of new seedlings after every occasional shower (our observations and those of Hermann, pers. comm.). This strategy is characteristic of the Mediterranean pattern and is not infrequent in South Africa, which has a climate very similar to our own (Schütz et al., 2002). In Falset, if post-summer rains occur, there are plants flowering and bearing fruit virtually all year round, except during the coldest months of December, January (February) and the summer months of July-August.

\section{Vegetative and floral development}

The growth of new branches, and especially new capitula, takes place from the basal vegetative zone and lasts throughout the cycle, which is conditioned by seasonal rainfall. Each individual plant usually lives for two months, and up to five months if protected by the mantle of trees. Thus the fruits on each capitulum gradually ripen over a period of time. Finally when the capitulum has scattered all its seeds and remains empty, a zone of necrosis appears on the peduncle, $1-3 \mathrm{~cm}$ from the base of the capitulum, causing it to bend over for a time and ultimately drop. The rest of the peduncle stays green until the whole plant shrivels up. This process

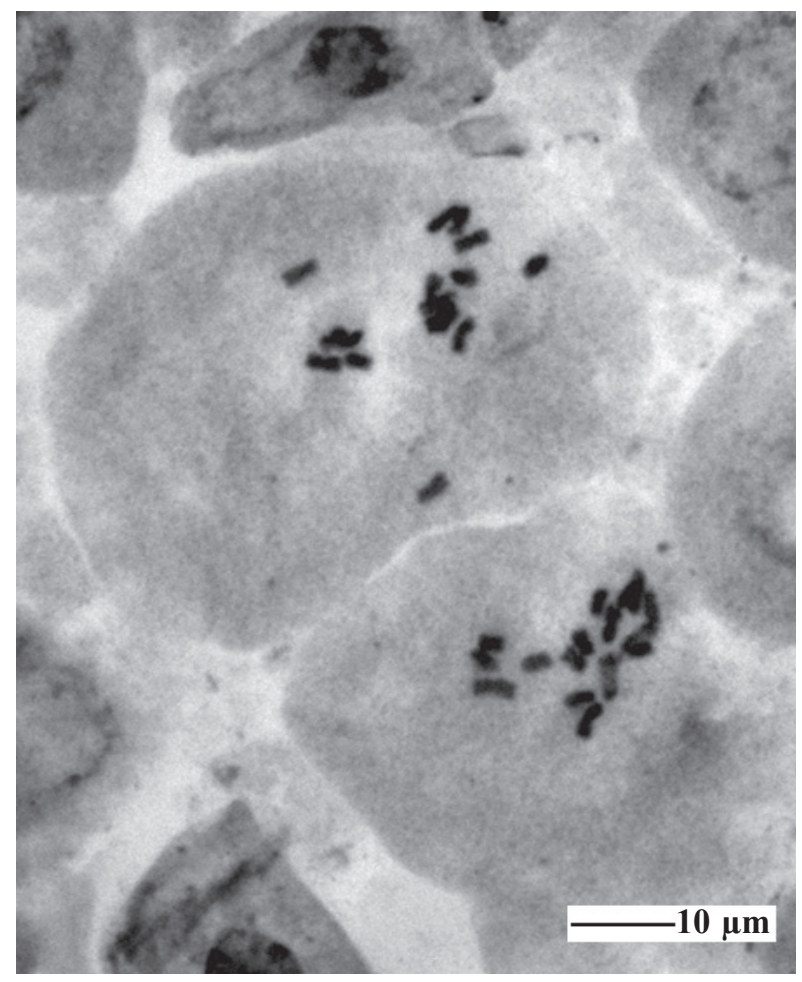

Figure 3. Somatic metaphases in a root meristem of $U$. nana subsp. nana $(2 n=16$; Falset, Molero32/2006 \& Vallverdú, BCN 46738).

is repeated for all the capitula: the apical capitula that drop are replaced by younger ones, which emerge from the lower branches, lengthening the peduncle. Obviously this very long peduncle (up to $12 \mathrm{~cm}$ in a plant whose overall height does not exceed $30 \mathrm{~cm}$ ) suggests that it was created first and foremost to facilitate pollination and the subsequent dispersal of the fruits.

Ursinia nana is a distinctly thermophilous and heliophilous plant which displays a clear Heliantheae light-energy dependency syndrome. When it is deprived of direct sunlight and the temperature is cool, the capitula are closed and pendulous (Fig. 4A) while the ligules are folded inwards, revealing their reddish underside. In order to reactivate it needs a rise in the ambient temperature (to at least $18^{\circ} \mathrm{C}$ ) and approximately $2-3$ hours of direct sunlight (observation carried out between 10.00 and 12.00 hours in April, 2007). After this period of prior warming, the plant becomes more vigorous and straightens up, the capitula become erect and open radially, deploying their ligules 
(Figs. 4B; 4C); the outer, sterile ligulate flowers open and take up a position perpendicular to the path of the sun, absorbing the radiation and apparently acting as a light signal to attract pollinators. As soon as the sun's radiation begins to decline and temperatures fall, the ligules close again and the capitulum bends over, taking up its night and morning rest position. This behaviour is very similar to that described by van der Walt (2001) for Ursinia cakilifolia DC, another annual species from South Africa, which is pollinated mainly by hymenopterans.

\section{Flower maturation, protandry and geitonogamy}

The outer ligulate flowers of the capitulum are sterile and produce no nectar; they seem to act simply as a visual signal, as well as reflecting the sun's radiation towards the disc flowers. Nonetheless the floral tube has a glandular secretory indumentum.

The disc flowers are hermaphrodite and protandrous (Fig. 5). Flower maturation takes place from close to the outer ligules towards the centre of the capitulum (Figs. 5A; 5B). The singenesious anthers are located (Figs. $1 \mathrm{~J} ; 1 \mathrm{~K}$ ) just below the corolla lobes; when the pollen is ripe the stylar colum emerges, ripping up anthers longitudinally and raising the pollen load onto the truncate, papillose, capitate stigma, and the pollen offers itself to be transported or consumed by possible visitors (Fig. 5C). In this phase the outer epidermis of the corolla lobes secrete small golden, refringent, terpenic drops (Liu et al., 2006) which can act as an olfactory reward for possible pollinators.

Later (Figs. 5C; 5D), beginning with another centripetal movement, the stylar arms open and offer the dry receptive inner surface, alongside the stylar channel. This surface, in principle, is ready to receive pollen from another flower, which can belong to the same capitulum, to another capitulum on the same plant, or to a different plant. Obviously the floral structure is designed for xenogamy through the action of pollinators; otherwise this expenditure of energy in preparation for cross-pollination would not take place. And though self-incompatibility has not been reported specifically for $U$. nana, it has been reported for very closely related annual species in South African populations of $U$. cakelifolia (van der Walt, 2001).
Despite this, geitonogamy appears to be the usual mechanism for pollen transfer in Falset: the stylar branches with their pollen load on the apex bend right over, the papillose terminal stigma deposits the pollen on the receptive surface of another nearby flower in the same capitulum, and self-pollination takes place (Fig. 5D). After a time (2-3 days), the style retracts into the corolla and the stylar arms fold back into a V-shape, just on a level with the anthers (Fig. 1L).

\section{Pollinator agents}

After 23 hours of observation in April-May 2007 in Falset, we concluded that the pollinators that usually frequent this enclave did not visit the flowers of Ursinia (0 visits!). This did not surprise us particularly because the species' usual pollinators in South Africa -assuming that there it is xenogamous- do not exist in Spain. Visits from generalist pollinators are at any rate a possibility. Apis mellifera is a frequent pollinator in this locality near Falset because several hives exist in the vicinity. The bees often visit the flowers of the thermophilous scrub, which includes some good melliferous species, but do not visit Ursinia, perhaps because they are not familiar with the flowers or because the capitulum is small and the peduncle, which is not strong, cannot support their weight. The small numbers of insects present in the cooler period of spring, which is the principal flowering period for Ursinia, may partially explain the absence of visitors. The lack of pollinators, however, was not obstacle to a significant and abundant crop of fruits (the ripening interval seems to be two weeks). We noticed quite by chance on 8 September 2008 that a few insects were visiting the flowers of Ursinia during the period of maximum insolation, from 12.00 to 15.00 hours. The most frequent visitor (22 visits recorded in three hours, for periods ranging from 30 seconds to three minutes) was a member of the Megachilidae family (Fig. 4E) provisionally identified as Heriades sp.-ㅇ. This genus habitually feeds on the pollen of Asteraceae. The plants received more infrequent visits -5 visits lasting 40-130 seconds- from Exoprosopa $s p$. (Bombiliidae) (Fig. 4D), and two visits from the very occasional butterfly Lycaena phaleas (Lepidopterae), which had only a few seconds of contact (Fig. 4F). There have been reports (Goldblatt et al., 1998) of pollination of other species of Ursinia from South Africa by pollen- and anther-consuming 


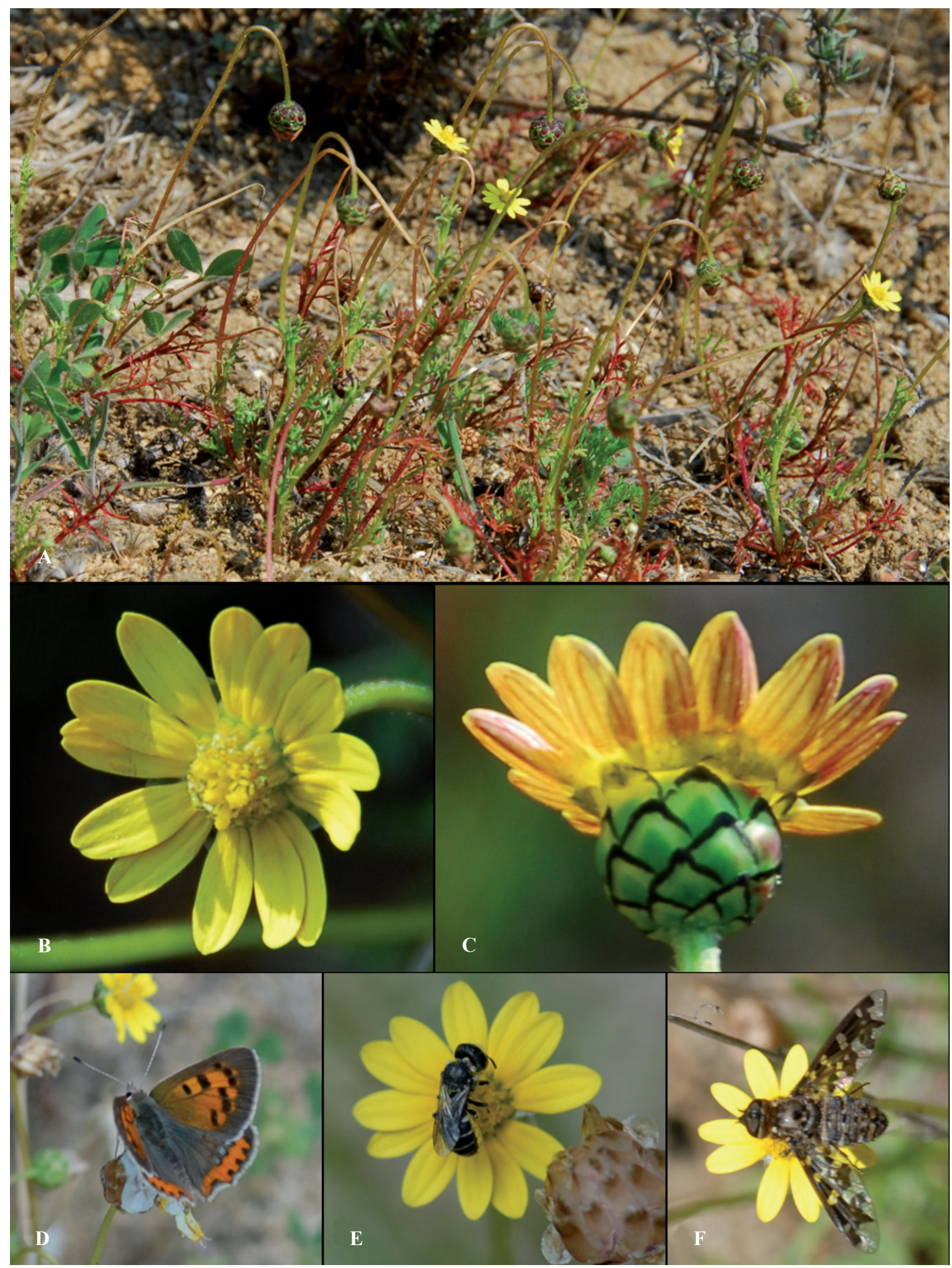

Figure 4. U. nana subsp. nana in Falset. (A), habitat; observe the nutant capitula; (B), open capitulum, apical view; (C), capitulum seen from beneath; observe the reddish venation of the ligules and the dark edge of the involucral bracts; (D)-(F), pollinators in Spain: (D), Lycaena phaleas (Lepidopterae); (E), Heriades sp. (Megachilidae); (F), Exoprosopa sp. (Bonbilidae). 
coleopterans (Scarabidae) but we did not observe this. Thus xenogamy does take place in the Falset population. We do not know if it is functional, however, and its reproductive significance, compared to autogamy, must in any case be very low, and virtually anecdotic. Nocturnal anthesis is not a factor in $U$. nana since the capitulum flowers are closed by the external ligules at dusk.

Symonides (1988) reported self-pollination and anemophily among species that invaded more or less disturbed habitats in South Africa. Ueckermann \& van Rooyen (2000), on the other hand, showed that Ursinia cakilefolia, which inhabits abandoned fields in Namaqualand (South Africa), is strongly dependent on insects for cross-pollination, that its self-incompatibility systems are operational and protandry is functional. Despite this, autogamy in this species attained $20 \%$.

\section{Insect-exclusion test}

In view of this, the very high production of seeds in May in the apparent absence of pollinators suggests self-compatibility without internal barriers. This is the only explanation for the large number of fruits that set without the usual pollinators, or with such infrequent visits. To confirm this hypothesis and rule out the possibility of anemophily we performed an insect exclusion test in the greenhouses at the JBB in which the wind was also absent as a possible vector (see section on Material and Methods).

We isolated 30 individuals and, after a 4-week ripening period, gathered the two most highly developed and mature capitula from each individual. We obtained 338 fruits from the 60 capitula The average number of fruits per capitulum was (8) $14.34(23) \pm 5.26$ (standard deviation). Fruit productivity in the greenhouse is appreciably lower than in wild plants, where it is close to $100 \%$. The cypselae gathered had the adult form but were smaller, with a very pale epicarp, and apparently immature; no subsequent test of germinative viability was carried out. Greenhouse conditions, with high humidity and no direct sunlight, probably contribute to this possible inability to attain full maturity. Once anemophily is ruled out, fruiting can only be explained by functional geitonogamy. This is illustrated in the photos in Fig. 5 , which show specimens used in this test.

It may be that $U$. nana is entomophilous in South Africa and that the Falset genotype/ecotype has derived towards self-pollination as a result of: a) the selection of immigrant genotypes/ecotypes which allow it to act as a pioneer species; b) the fact that it comes from "autogamous" seeds selected for garden use (if this is indeed its origin). The "shift" towards a self-pollination system (caused by one of these factors) which enhances its invasive action involves a breakdown of herkogamy and of genetic self-incompatibility (if self-incompatibility rates in $U$. nana are really similar to those of $U$. cakilifolia in South Africa). The production of autogamous ecotypes of otherwise allogamous plants under the selective pressures exerted by the absence of suitable pollinators is reported by Faegri \& van der Pijl (1980).

\section{Production, ripening and dispersal of fruits}

After lengthy exposure to the sun, the rise in temperature in the capitulum speeded up the ripening of the cypselae (Figs. 6A-6E) and the dehydration of the five young imbricate perianth scales surrounding the floral tube (Figs. 6B; 6C). The mechanical effect of drying causes these scales to unfold spirally until they reach a horizontal position (Fig. 6E) and raise the cypsela (released by the abscission of the thalamus from its base) by sliding it along the \pm curved utricular palea (Fig. $6 \mathrm{C}$ ), until it is shown to be open on the capitulum (Figs. 6A; 6D). The process is rapid, sometimes being completed in minutes. It occurs rhythmically, from the edge towards the centre. There is room in the capitulum for a maximum of 3-5 fruits with their perianth scales open (Fig. 6D). As they drop, their place is taken by the nearest internal fruits, which expand. Thus the fruits are exposed to any breeze or draught which, if strong, warm and upwardmoving, can scatter the seeds over a considerable distance (medium- and long-distance dispersal). The position of the cypsela -which is obliquely sloping with respect to the open perianth scales (when they come from the outermost fruits on the capitulum, Fig. 1H), like a rudder (Figs. 6C; 6F)facilitates their linear movement by protecting it from turbulence. Thus anemochory is the primary medium- and long-distance dispersal mechanism, as in other Ursinia. Ursinia cakilefolia is known in the Karoo region of South Africa as the "parachute daisy" because of its anemochorous dispersal (Van der Walt, 2001). 


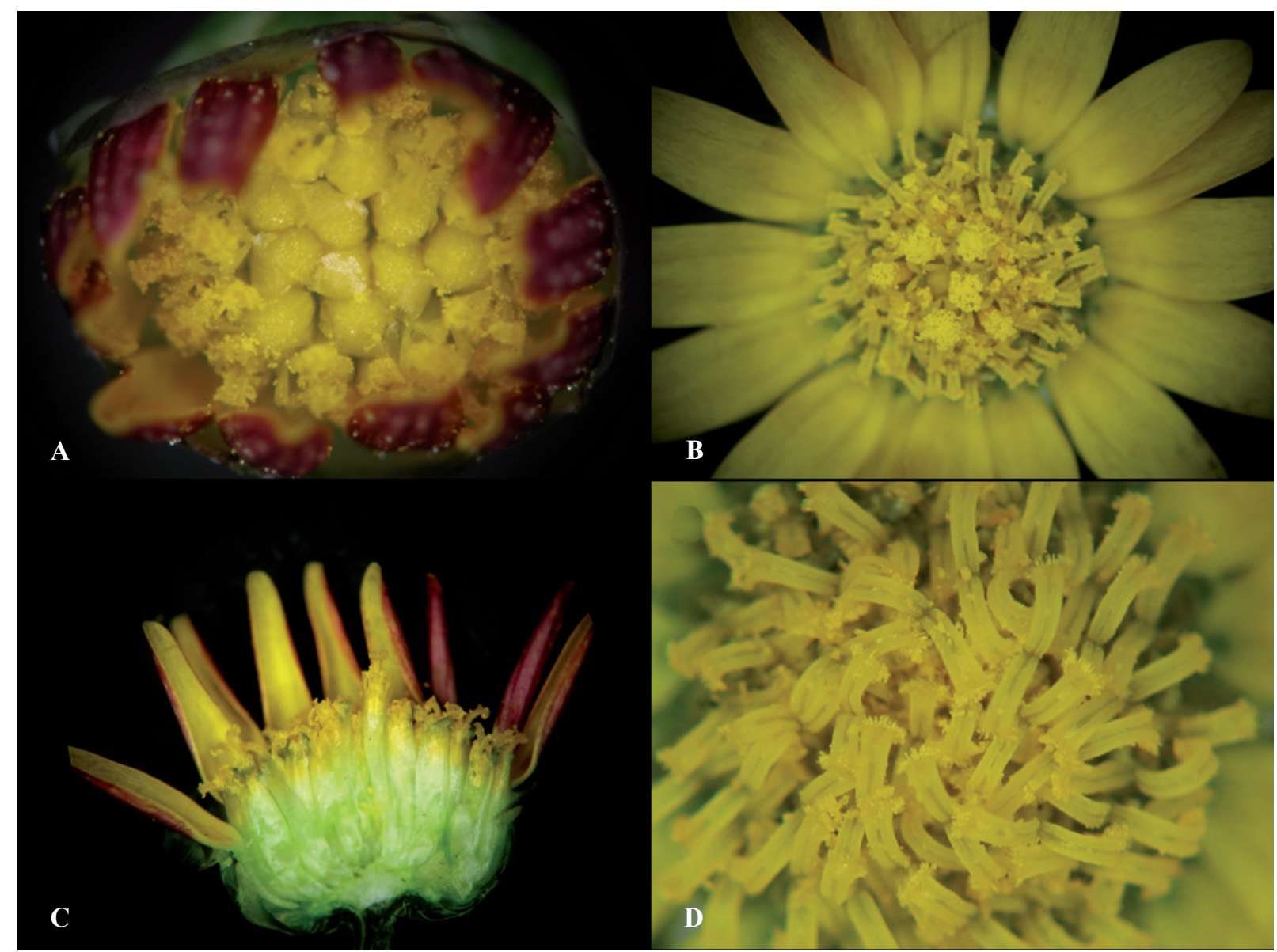

Figure 5. Reproductive systems of $U$. nana (from Falset, cultivated in the JBB). (A), Initial centripetal protandry in the capitulum: the pollen load on the closed stylar column emerging in the outermost flowers, the inner flowers still closed; (B), polar view of the capitulum; protandry in the advanced phase: central $\hat{\delta}$ flowers with their pollen load, peripheral o flowers opening their stylar arms to facilitate geitonogamy; (C), longitudinal section of a capitulum in the same phase as in the previous photo; note that the flowers in the centre with initial protandry are rising with their pollen load; the more mature outer flowers are opening their stylar arms; (D), middle-late o phase of anthesis, geitonogamy fully operational; the bent stylar arms with pollen-bearing stigma papillae fertilize the receptive surfaces of the neighbouring flowers.

The most widespread dispersal method, however, is short-distance and gravitational (Fig. 6F): the slightest movement of the plant causes the ripe fruit to fall, and most are scattered within a short radius of the individual (Fig. 6G), producing a plentiful seed bank.

Fruit production per capitulum is practically the same as flower production; nearly all the flowers are viable. Each capitulum bears (20)26-35 fruits. Since each individual produces (2)6-27 capitula during its life cycle, the theoretical maximum number of seeds per individual is 1,000 . The seed bank scattered round the population contains a very large number of seeds and the white outer scales of the cypselae make it visible to the naked eye (Fig. 6G). The dormancy period appears to be very short and, as is shown by the large number of seedlings produced after isolated showers, the seeds' germinative potential also remains high from one year to the next. Any seasonal shower occurring in conjunction with temperatures not below $10^{\circ} \mathrm{C}$ (Schütz et al., 2002) gives rise to an abundant crop of seedlings. In view of this high rate of germination during the first year (we do not know if it is maintained in the following 2-3 years), the ability of this species to colonize new habitats seems to be at least as high as that of $U$. cakilefolia, whose fruits germinate after 3-7 days in cultivation if properly watered, but germinate irregularly in the wild where they have to compete with other master growing weeds (Van der Walt, 2001). 


\section{Germination ability}

Of the 50 cypselae sown in Petri dishes, 33 ultimately germinated (68\%): after 5 days 3 cypselae had germinated (6\%); after 10 days 19 more had germinated (44\%, cumulative); after 15 days, 9 more (62\%, cumulative); and after 19 days, 2 more $(68 \%$, final).

At the same time 50 cypselae were sown in the greenhouse at the JBB of which 46 ultimately germinated (92\%). After 5 days none had germinated; after 10 days 7 had germinated (15\%); after 15 days, 18 more (50\%, cumulative); after 20 days, 14 more (78\%, cumulative); and after 25 days, 7 more (92\%, final).

In the Petri dishes the seeds began to germinate earlier but the final rate of germination was lower. This may be due to several factors and on the basis of available data only a hypothetical explanation can be offered. Sowing in the greenhouse is technically much more correct and was ultimately more successful in terms of the percentage of germination: the results were close to horticultural standards for U. nana announced on the internet (Clothier, 2003) which indicate that the seeds germinate quickly and easily 14-30 days after sowing at natural conditions of $55-66^{\circ} \mathrm{F}\left(12-16^{\circ} \mathrm{C}\right)$.

\section{Predation by ants: a possible biological control of the invasion?}

In mid-May 2007 we observed that the highly visible seed rain in the soil surface of some colonies (Fig. 6G) were being partially or totally depleted by ants, which collected them in large quantities (Fig. 6H) and carried them to their nest (Fig. 6I). They were granivorous ants of the species Messor barbarus (L.), which is present nearly all along the Mediterranean coastline as far as Turkey. They collect a wide variety of seeds and small fruits, as well as scraps of leaves, small twigs and other objects (even small pebbles) which they do not use. In Falset they clearly prefer the fruits of Ursinia to others that are available in the area. This apparent myrmecochory of Ursinia must be interpreted as predation because Ursinia is an annual species and the depth of the ant nest is not suitable for the germination of its fruit. Moreover, the pericarp is relatively soft, so it is very likely that the fruits are consumed by the ants. This is the only explanation for the massive removal of these fruits in some colonies of the three nuclei of population.

Predation of the fruits by Messor barbarus can significantly affect the plant's colonizing effect in Falset and, if the species eventually becomes naturalized in Spain, can help control populations. In South Africa Messor capense affects the distribution and productivity of certain species associated with myrmecochory in pastures in the Karoo region (Dean \& Yeaton, 1993); U. nana is briefly mentioned in a list of potential depredators of the plants of the fynbos but its precise relationship to the insect is not specified.

The possible role of chemical repellents such as the sesquiterpenes detected in U. nana (Liu et al., 2006) in biotic interactions with herbivores and other predators is unknown. In Namibia (Burke, 1997) $U$. nana is found in meadows where herbivores habitually graze, but this activity is not a factor in Falset.

\section{Naturalization or extinction? The invasion's possible evolution}

Ursinia nana is a strictly silicicolous species, which is thermophilous, heliophilous and somewhat nitrophilous, and requires seasonal rainfall. The main limiting factor for the expansion of these populations in the warm, sunny Priorat region is probably the substratum and of course the seasonal rains, which in some years may be insufficient. Sand of granitic origin is confined to an area within a radius of $2-3 \mathrm{~km}$ of Falset; beyond this the nearest sandstone is in $\mathrm{La}$ Cubeta de Mora, a considerable distance away. It seems unlikely that the Palaeozoic schist surrounding these granite outcrops or the nearby limy soil provide a substratum conducive to its propagation. In view of the easy propagation of the adventive's seeds, its natural evolution lies in the colonization of other nearby enclaves with the same substratum, but it is unlikely to spread any farther.

Another obstacle to its propagation and consolidation in the area may be depredation of the seed bank by certain granivorous ants, as commented above.

It is impossible to predict its future evolution. It depends largely on the germinative capacity of its fruits and on their ability to withstand some years of non-germination owing to scant rainfall without entirely losing their germinative potential. However, annual rainfall in the area is seldom less than $400 \mathrm{~mm}$, so severe droughts are not frequent. 


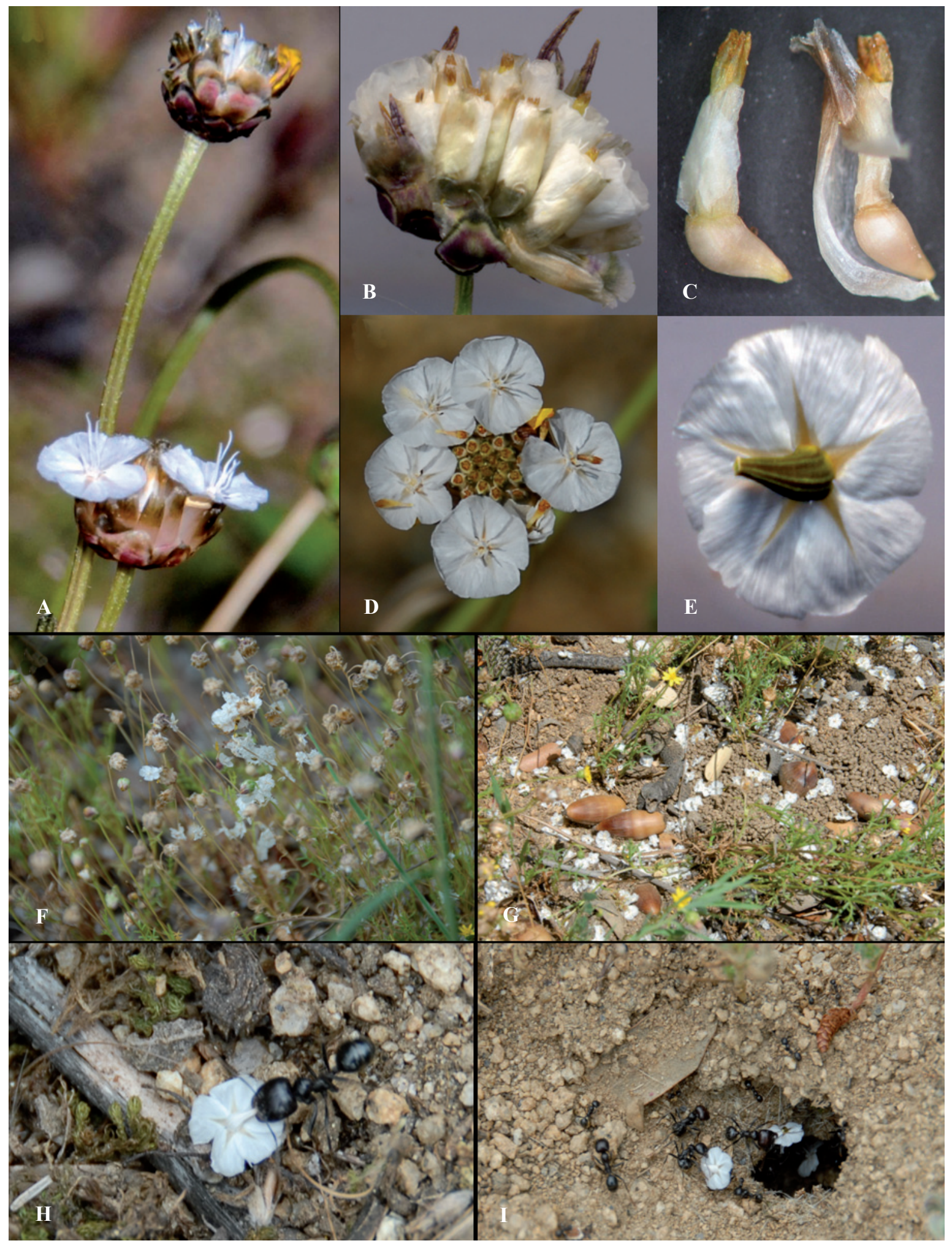

Figure 6. Fruit ripening and dispersal. (A)-(E), structure and ripening of the capitulum and fruit: (A), mature capitula on long peduncles with fruits ready for dispersal; observe the internal perianth laciniae arising from the base of the fruit's receptacular scales; (B), internal structure of the capitulum with initial fruits, paleae and perianth scales covering the floral tube; (C), two young cypselae with and without a utricular palea; the white perianth scales cover the floral tube; (D), five open cypselae (the maximum number permitted by the capitulum) about to be dispersed; (E), a complete cypsela, with fruit and open perianth scales, seen from the back; (F), anemochorous and gravitational dispersal of the cypselae; (G), Fruit rain highly visible on the substratum; (H) Messor barbarus gathering a fruit; (I), ants carrying the fruits and storing them in their nest. 
As a pioneer species it can come into competition with certain native plants for the slightly altered, disturbed spaces in the more superficial outcrops of granite substratum. For the time being, however, it does not seem to have a serious effect on the floral composition of the acidophilous therophytic pastures which constitute the more natural and least disturbed vegetation. Nor does it currently compete for the usual pollinators in the area: this is due at least partly to its early flowering time, few pollinators being present when it flowers, and to their unfamiliarity with it. In agronomical terms it seems unlikely to have a harmful effect on the local agriculture because Ursinia nana does not grow at present on farmland or colonize grassland or dense pastures.

It would be very interesting to study the evolution of these populations in depth, focussing on both their reproductive biology and population dynamics and their genetic diversity. Another interesting topic is the evolution of the germinative capacity of the seeds over time. This could provide a sounder basis for forecasting the evolution of these populations, the prospect -or lack of it- of their becoming definitively naturalized, and, in the shortand medium-term, the likely behaviour of other invasive species of the same origin. Ursinia nana affords ideal conditions for a follow-up because of its isolated location, which has undergone slight anthropic influence as yet, and the still relatively small and variable size of its populations, which are therefore manageable.

\section{ACKNOWLEDGEMENTS}

My thanks are due to my companion of floristic prospecting expeditions, Jordi Vallverdú, with whom I shared the discovery of this alien and some uncomfortable but gratifying field observations. I am indebted to C. Oberprieler and P. Hermann by their partial help in the identification of this neophyte and for the additional information received on several issues. I express my appreciation also to M. Beny, the gardening technician at the JBB, who cared for our collections, to $\mathrm{X}$. Espadaler who identified the ant, and to J. Bosch who assisted in identifying the Megachilida. The latter are both researchers at the CREAF (Universitat Autònoma de Barcelona). I am grateful to J. Aldasoro of the Jardín Botánico de Madrid, who helped us to identify the other insects. I also thank my colleagues in the BIOC working group: M. Martinell who skillfully drew the map, M. Bosch who confirmed certain findings, and A. Rovira who provided technical and field assistance. Special gratitude goes to C. Blanché for his critical reading of the manuscript and pertinent observations, which considerably enriched it.

\section{REFERENCES}

Bond, P. \& Goldblatt, P. 1984. Plants of the Cape flora: a descriptive catalogue. J. S. African Bot., Suppl. 13.

Burke, A. 1997. The impact of large herbivores on floral composition and vegetation structure in the Naukluft Mountains, Namibia. Biodiversity and Conservation 6(9): 1203-1217.

Clothier, T. 2003. Annual/Biennial Germination Database. Retrieved 20 Aug, 2009, from http://tomclothier.hort.net/ index.html

Cullen, J. 2000. Ursinia Gaertn. In: Cullen et al. (Eds.), The European Garden Flora 6(4). Cambridge University Press, Cambridge: 598.

Dean, W. R. J. \& Yeaton, R. I. 1993. The influence of harvester and Messor capensis nest-mounds on the productivity and distribution of some plant species in the southern Karoo, South Africa. Pl. Ecol. 106(1): 21-35.

Everett, T. H. 1982. The New York Botanical Garden illustrated encyclopedia of horticulture 10. Garland Publishing, New York.

Faegri, K. \& Van der Pijl, L. 1980. The Principles of Pollination Ecology ( $3^{\text {rd }}$ Ed.). Pergamon Press, Oxford.

GCW. 2007. Global Compendium of Weeds Website - Hawaiian Ecosystems at Risk (HEAR). Retrieved 20 Aug, 2009, from http://www.hear.org/gcw/index.html

Goldblatt, P., Berhardt, P. \& Manning, J. C. 1998. Pollination of Petaloid Geophytes by Monkey Beetles (Scarabaeidae: Rutelinae: Hoplini) in Southern Africa. Ann. Missouri Bot. Gard. 85(2): 215-230.

Haessler, I. 1967. Chomosomenzahlen aus der gattung Ursinia. Mitt. Bot. München 6: 531-539.

Hilliard, O. M. 1977. Compositae in Natal. University of Natal Press, Pietermaritzburg.

Liu, Y., Zhang, S. \& Abreu, P. J. M. 2006. Heterocyclic terpenes: linear furano and pyrroloterpenoids. Nat. Prod. Rep. 23: 630-651.

Molero, J. \& Rovira, A. 2002. Kariological evolution and molecular phylogeny in Macaronesia dendroid spurges (Euphorbia subsect. Pachycladae). Plant Syst. Evol. 231: 109-132.

Prassler, M. 1967. Revision der gattung Ursinia. Mitt. Bot. München 6: 363-478.

Retief, E. \& Herman, P. P. J. 1997. Plants of the northern provinces of South Africa: keys and diagnostic characters. Strelitzia 6: 342-343.

Scott, J. K. \& Panetta, F. D. 1993. Predicting the Australian weed status of southern African plants. J. Biogeogr. 20: 87-93.

Schütz, W., Milberg, P. \& Lamont, B. B. 2002. Seed Dormancy, After-ripening and Light Requirements of Four Annual Asteraceae in South-western Australia. Ann. Bot. (Oxford) 90: 707-714.

Symonides, E. 1988. On the ecology and evolution of annual plants in disturbed environments. Vegetatio 77: 21-31.

Ueckermann, C. \& van Rooyen, M. W. 2000. Insect pollination and seed set in four ephemeral plant species from Namaqualand. S. African J. Bot. 66(1): 28-30.

Van der Walt, L. 2001. Ursinia cakilefolia DC. South African National Biodiversity Institute. Retrieved 6 Jun, 2007, from: http://www.plantzafrica.com/planttuv/ursiniacakil.htm

Van Wyk, B. \& Malan, S. 1988. Field guide to the wild flowers of the Witwatersrand and Pretoria region, including the Magaliesberg and Suikerbosrand. Struik, Cape Town. 